\author{
C. Becker · D. Brepohl · H. Feuchtmayr · E. Zöllner \\ F. Sommer · C. Clemmesen · U. Sommer · M. Boersma
}

\title{
Impacts of copepods on marine seston, and resulting effects on Calanus finmarchicus RNA:DNA ratios in mesocosm experiments
}

Received: 24 March 2004/ Accepted: 23 August 2004/Published online: 24 September 2004

(C) Springer-Verlag 2004

\begin{abstract}
We investigated the impact of copepods on the seston community in a mesocosm set-up, and assessed how the changes in food quantity, quality and size affected the condition of the grazers, by measuring the RNA:DNA ratios in different developmental stages of Calanus finmarchicus. Manipulated copepod densities did not affect the particulate carbon concentration in the mesocosms. On the other hand, chlorophyll $a$ content increased with higher copepod densities, and increasing densities had a positive effect on seston food quality in the mesocosms, measured as $\mathrm{C}: \mathrm{N}$ ratios and $\omega 3: \omega 6$ fatty acid ratios. These food quality indicators were significantly correlated to the nutritional status of $C$. finmarchicus. In contrast to our expectations, these results suggest a lower copepod growth potential on higher quality food. However, in concordance with earlier studies, we found that when copepods were in high densities the large particles $\left(>1000 \mu \mathrm{m}^{3}\right)$ decreased and that the smaller particles $\left(<1000 \mu \mathrm{m}^{3}\right)$ increased in number. These patterns were closely linked to the condition of C. finmarchicus, which were of better condition (RNA:DNA ratios) with increasing biovolumes of large particles, and, conversely, lower RNA:DNA ratios with
\end{abstract}

Communicated by O. Kinne, Oldendorf/Luhe

C. Becker $(\bowtie) \cdot$ H. Feuchtmayr · E. Zöllner

Max-Planck-Institut für Limnologie,

Postfach 165, 24302 Plön, Germany

E-mail: beckerc@kbs.msu.edu

Tel.: + 12696712274

D. Brepohl · F. Sommer · C. Clemmesen · U. Sommer Leibniz-Institut für Meereswissenschaften,

IFM-GEOMAR Marine Ökologie,

Düsternbrooker Weg 20, 24105 Kiel, Germany

M. Boersma

Alfred-Wegener-Institut für Polar und Meeresforschung,

Biologische Anstalt Helgoland, Postfach 180,

27483 Helgoland, Germany

Present address: C. Becker

WK Kellogg Biological Station, Michigan State University, Hickory Corners, MI 49060, USA increasing biovolumes of smaller particles. Consequentially, the selective grazing by copepods stimulated increased biovolumes of smaller plankton, and this increase was responsible for the increased food quality, in terms of $\mathrm{C}: \mathrm{N}$ and $\omega 3: \omega 6$ ratios. Thus, we conclude that the decreasing growth potentials of $C$. finmarchicus were a result of a decrease of favourably sized food particles, induced by copepod grazing.

\section{Introduction}

Zooplankton production can be constrained by many factors, and food quantity is one of these factors. However, many studies have found retarded developmental rates even on high food concentrations, suggesting limitation by food quality rather than food quantity (e.g. Kleppel and Burkart 1995; Villar-Argaiz and Sterner 2002). Several characteristics of the food can affect quality and thus induce changes in zooplankton development. Toxicity of various species of phytoplankton can have a great impact on the copepod community (Turner et al. 1998; Frangoulos et al. 2000; Schmidt et al. 2002). Several diatoms have proven to have negative impacts on copepod fecundity and egg viability (reviewed in Paffenhöfer 2002; Ianora et al. 2003). The exact causes of these negative impacts are still under discussion, both toxicity as well as nutritional deficiency have been invoked. Other constraints on copepod development can be caused by the size and morphology, as well as by the mineral and biochemical composition of the food (Kleppel and Burkart 1995; Villar-Argaiz and Sterner 2002). The content of various fatty acids and, more specifically, the ratio between two classes ( $\omega 3$ and $\omega 6$ fatty acids) have been shown to correlate closely with egg production in a number of copepod species (Jónasdóttir 1994; Jónasdóttir et al. 1995), whereas low-nitrogen foods have a negative impact on copepod growth and reproduction (Kiørboe 1989). 
Calanoid copepods generally have a preference for larger particles; they do not feed on protists $<5-\mu \mathrm{m}$ in the laboratory and preferably graze on food particles $>10-\mu \mathrm{m}$. This behaviour has been identified for freshwater copepods (Rothhaupt 1997; Sommer et al. 2001) as well as for marine copepods (Frost 1972, 1977). As a result, in copepod-dominated ecosystems, larger particles are strongly grazed, while mostly small particles prevail (Rothhaupt 1997; U. Sommer et al. 2001, 2003). This pattern is most likely a combination of grazing pressure and the longer generation times for larger phytoplankton cells. Alternatively, the increase of smaller particles could be a consequence of copepods breaking larger particles into smaller ones (O'Connors et al. 1976). Copepods do not only select their food according to size, but can also distinguish between similar sized particles of different nutritional quality and mobility (Paffenhöfer and Van Sant 1985; Cowles et al. 1988). Moreover, zooplankton grazing can impact the plankton nutrient stoichiometry, resulting in increased C:N or C:P ratios (Sterner and Hessen 1994; Rothhaupt 1997), which can cause a decrease in food quality. Hence, copepods can impose large impacts on the composition of the plankton community. Active food selection induces a higher grazing pressure on the "better" food particles and the proportion of these decreases. Hence, increasing copepod densities result in increased food competition and should be reflected in slower copepod development.

Copepod growth or nutritional status can be determined by several methods. Egg production is a common technique in both laboratory and field studies (e.g. Jónasdóttir et al. 1995; Kleppel and Burkart 1995). This trait can serve as a good indicator of current nutritional status of wild caught copepods by studying the egg production over a short period of time $(\sim 24 \mathrm{~h})$. However, this is not an effective method when copepod reproduction is low. Another method is to study the effects of various treatments on life-history traits (e.g. Twombly et al. 1998; Villar-Argaiz et al. 2002). This procedure is time consuming and can last for weeks, thus making it unsuitable to test for food quality effects fluctuating over short time periods. A third possibility is through measurements of ribonucleic acid (RNA) and deoxyribonucleic acid (DNA). The ratio of the two (RNA:DNA) and the RNA content alone have proven to be a useful tool in determination of nutritional status of various zooplankton organisms (e.g. Båmstedt and Skjoldal 1980; Båmstedt 1983; Saiz et al. 1998; Wagner et al. 1998; Vrede et al. 2002) and fish larvae and juveniles (Clemmesen 1993, 1994, 1996; Clemmesen et al. 2003). Typically, an increased RNA:DNA ratio indicates a higher growth potential. Food quality changes can induce a RNA:DNA response in freshwater daphniids within $5 \mathrm{~h}$ (Vrede et al. 2002). For copepods, this response is probably slower, due to lower growth rates and longer generation times of copepods. In marine field studies, significant correlations between chlorophyll $a$ concentrations (indicator of food), copepod egg pro- duction and the copepod RNA:DNA ratios have been described (Nakata 1990; Nakata et al. 1994; Laabir et al. 1998; Saiz et al. 1998). In laboratory studies C. finmarchicus RNA:DNA ratios are good indicators of food availability (Wagner et al. 1998, 2001).

When investigating the impacts of different feeding conditions on the plankton community in a close-tonatural environment, mesocosms are the method of choice. With this set-up one can alter specific environmental conditions (e.g. nutrient additions) on a largescale community, under otherwise "natural" conditions. Thus, studies in mesocosms combine benefits of field and laboratory studies.

In a mesocosm study we investigated the impact of manipulating the density of copepods on the phytoplankton community. Moreover, we determined how these changes affected the copepod nutritional status by monitoring the copepod RNA:DNA ratios. We selected a predominant copepod species in northern ecosystems, C. finmarchicus, which is an important prey for several commercially important fish species in the northern Atlantic. Hence, the biology of $C$. finmarchicus has been of considerable scientific interest (e.g. Hirche 1996; Richardson et al. 1999; Kaartvedt 2000).

\section{Materials and methods}

This study was performed as a part of a larger project aimed at determining the impact of different zooplankton organisms on freshwater, brackish and marine food webs. The effects have been studied on various levels from bacteria to zooplankton (see F. Sommer et al. 2003; U. Sommer et al. 2001, 2003; Zöllner et al. 2003; Becker et al. 2004). In this paper we focus on interactions between the phytoplankton community and the nutritional status of the zooplankton.

\section{Mesocosms}

Two mesocosm experiments were conducted at Trondheim Marine Systems Research Infrastructure in Hopavågen, Sletvik, Norway, during April and May 2002. The first experiment was performed between 20 and 26 April and the second between 2 and 8 May. In both experiments ten transparent polyethylene mesocosms were installed $\left(2.0 \mathrm{~m}\right.$ long; $\left.1.7 \mathrm{~m}^{3}\right)$ and filled with the natural plankton community by lowering the bags down to about $3 \mathrm{~m}$ depth and pulling them to the surface, for more information on the general set-up see Sommer et al. (2001). We reduced the mesozooplankton in the mesocosms with repeated hauls with $250-$ and $150-\mu \mathrm{m}$ plankton nets. Afterwards the mesocosms were enriched with a logarithmic density gradient of wild caught zooplankton. These were captured with a relatively large meshed plankton net $(500-\mu \mathrm{m})$, which in both experiments enabled us to create a grazing community of "larger" zooplankton, consisting of Calanus finmarchicus 
(70-80\%) (copepodite stages 3-5), Centropages hamatus and $C$. typicus (together 3-11\%) and Oithona sp. (6-10\%) and a few Acartia sp., Temora longicornis and Pseudocalanus elongatus as described by Saage (2003). From this mixture, inoculates were taken in order to establish a density gradient for experiment 1 with: 0 (control), 0.3, 0.9, 2.7 and 8.1 copepods $1^{-1}$ and for experiment 2 with: 0 (control), 1.3, 2.5, 5 and 10 individual copepods $1^{-1}$. The mean copepod density directly outside the mesocosms in the fjord was 2.25 $( \pm 2.6 \mathrm{SD})$ copepods $1^{-1}$ during both experiments. On the other hand, in a depth profile down to $15 \mathrm{~m}$ the densities increased with depth and over the whole water body averaged around 12 copepods $1^{-1}$ (from Saage 2003). The mesocosms were monitored for phytoplankton and zooplankton density and composition at day 0 (start), day 3 and day 6 . After sampling on day 6 , the experiments were terminated. Before sampling, all mesocosms were mixed with a Secchi-disk, in order to avoid sampling errors due to aggregations or sedimentation. The mean water temperature in both experiments was $8.3^{\circ} \mathrm{C}$, and the salinity differed slightly between experiment 1 (31.7 psu) and experiment 2 (33.1 psu). At each sampling, 10-1 of water was collected, from which several plankton parameters were monitored: (1) composition of phytoplankton, ciliates and heterotrophic nano-flagellates, (2) mineral composition of particulate matter (C:N:P) and (3) fatty acid (FA) composition. Parallel to the sampling the chlorophyll $a$ content was measured at $1 \mathrm{~m}$ depth with a "bbe FluoroProbe" (Beutler et al. 2002). Zooplankton samples were taken with a vertical tow through the entire water column of the mesocosm with a $55 \mu \mathrm{m}$ plankton net. The samples were fixed in formaldehyde, and identified and counted under a dissecting stereomicroscope. In order to investigate the nutritional status of the copepods we focused on the dominant copepod $C$. finmarchicus and used RNA:DNA ratios as a proxy for nutritional condition. These animals were sampled at the same time and with the same technique as the zooplankton described above. The captured zooplankton from each mesocosm was concentrated in a 200-ml bottle and kept dark and cooled on ice before sorting into $C$. finmarchicus copepodite stages. The sampling process and the succeeding identification took about $4 \mathrm{~h}$. All individuals were stored solitary in Eppendorf tubes at $-18^{\circ} \mathrm{C}$, transported on dry ice to the home institutes and then stored at $-74^{\circ} \mathrm{C}$ until further analysis.

\section{Laboratory study}

Parallel to the first mesocosm field experiment, we performed a laboratory experiment to investigate how differences in food quantity and quality affect nutritional conditions for C. finmarchicus. The primary goal with the laboratory experiment was to investigate if the nutritional condition of $C$. finmarchicus followed the expected pattern of changes in food quality and quantity (e.g. by being higher under good feeding conditions and lower in starving situations). Another important objective of the laboratory experiment was to establish which copepodite stages should be focused upon in the mesocosm studies, as the responsiveness of copepod RNA:DNA ratios is strongly stage dependent (Wagner et al. 1998, 2001). We had five food treatments, in three of these we used water from the mesocosms that was manipulated by different densities of copepods: low-cop, medium-cop and high-cop (corresponds to: 0, 0.3 and 8.1 copepods $1^{-1}$, respectively). The other two treatments were manipulated artificially in order to induce two extreme treatments used in copepod growth comparisons. These conditions were obtained by sterile filtering $(0.2-\mu \mathrm{m})$ water from Hopavågen, which we used for the starvation treatment. For the other extreme treatment we added about $1 \mathrm{mg} \mathrm{C} 1^{-1}$ of a mixture of Rhodomonas sp./Tetraselmis sp. (Rho/Tet) to the filtered water. The algae were obtained from stock cultures of Trondheim Marine Systems Research Infrastructure, Norway. We started the laboratory experiment on day 3 of the first mesocosm experiment and continued for five more days. Since the first mesocosm experiment was terminated after 6 days and replaced by new bags after 7 days, we stored food suspensions collected on day 7 for use in the laboratory experiment at $8^{\circ} \mathrm{C}$ in darkness for $24 \mathrm{~h}$. At the start of the laboratory experiment we captured copepods from the natural environment as above, and these animals were concentrated in a beaker. From this we added aliquots corresponding to 15 individuals of mixed stages of $C$. finmarchicus per replicate. The animals were cultivated in 1.5-1 PET plastic bottles, which were stored in a tank with continuous flow of fjord water, with the same temperature as in the fjord $\left(8.3^{\circ} \mathrm{C}\right)$. The different food suspensions were changed daily by gently siphoning the water through a small tube covered with $100-\mu \mathrm{m}$ gauze to avoid loss of animals. Around 200-ml of the "old" suspension remained, before the bottles were gently refilled with fresh food suspensions. After 5 days, the experiment was terminated and the animals were sampled for RNA:DNA analysis as above.

\section{Analyses}

The phytoplankton species composition in the mesocosms was monitored using an inverted microscope, with identification of most organisms to genus level. In order to investigate the effects of the total plankton size distribution on the nutritional status of the copepods (RNA:DNA), we combined the phytoplankton data with the measurements of ciliates and heterotrophic nanoflagellates. The total biovolumes were calculated as sum parameters for all particles with a mean cell volume smaller and larger than $1000 \mu \mathrm{m}^{3}$.

The particulate fraction of the seston was analysed for nutrient $(\mathrm{C}: \mathrm{N}: \mathrm{P})$ and fatty acid composition. For seston nutrient analyses, 0.3-1.0-1 water was pre-filtered 
over a 100- $\mu \mathrm{m}$ gauze before being collected on precombusted, and, for phosphorus, acid washed, $\mathrm{GF} / \mathrm{F}$ glass fibre microfilters and dried overnight at $60^{\circ} \mathrm{C}$. Total nitrogen and carbon were measured using a FISONS NA2000 elemental analyser. Total phosphorus was determined by an ammonium-molybdate method by measurements on a spectrometer at 720-nm. The fatty acid spectra were also established for the seston in the mesocosms. We pre-filtered 2-5-1 over 250- $\mu \mathrm{m}$ gauze, before filtering on a $\mathrm{GF} / \mathrm{C}$ filter that was subsequently stored under $\mathrm{N}_{2}$ gas at $-18^{\circ} \mathrm{C}$ until further processing. Fatty acids were extracted, esterified and analysed on a gas chromatograph (GC) according to Wiltshire et al. (2000), with the GC temperature settings of von Elert (2002). To quantify the fatty acid content we used internal standards of heptadecanoic and tricosanoic fatty acid methyl esters.

The nutritional status of C. finmarchicus was determined with RNA:DNA measurements, and quantified fluorimetrically with ethidium bromide and ribonuclease A using a modification of the method of Clemmesen (1993). The response of the RNA:DNA ratios to changes in food availability and quality are dependent on the developmental stages of the copepods (Wagner et al. 1998, 2001). Hence, to get a good estimate of the nutritional status of $C$. finmarchicus, each copepodite stage was identified. To get a distinct RNA:DNA signal four to five individuals of the same copepodite stage were pooled for each measurement. A variability test was performed in order to define the variability between aliquots of one homogenate. This test should be used as an indicator of whether the method by Clemmesen (1993) was applicable to copepodite stages. In this test we measured 15 parallel aliquots from the same homogenate using a pooled sample of mixed stages of C. finmarchicus copepodites.

\section{Results}

\section{Variability test}

We found little variation when we measured the aliquots of the same homogenate of Calanus finmarchicus copepodites, indicating good reproducibility of the method applied. The coefficient of variation was $<4.4 \%$ (RNA:DNA) (Table 1).

Table 1 Calanus finmarchicus. Mean DNA and RNA contents and RNA:DNA ratios from 15 parallel determinations of the same homogenate of pooled copepodites ( $\pm \mathrm{SD}$ in parentheses) $(C V$ coefficient of variability)

Parameters DNA contents $(\mu \mathrm{g})$ RNA contents $(\mu \mathrm{g})$ RNA:DNA

\begin{tabular}{llll}
\hline Conc. & $2.40(0.06)$ & $5.57(0.21)$ & $2.32(0.10)$ \\
CV $(\%)$ & 2.7 & 3.7 & 4.4 \\
\hline
\end{tabular}

Laboratory study

In the laboratory study conducted over 5 days, we recorded differences in RNA:DNA ratios between copepodite stage (two-way ANOVA; stage, $P<0.001$ ) and the interaction between copepodite stage and the treatments (two-way ANOVA; stagextreatment, $P<0.001)$; the treatments alone did not induce significant differences upon RNA:DNA ratios (two-way ANOVA; treatment, $P=0.20$ ) (Fig. 1). In a separate analysis of the different stages we found that the RNA:DNA ratios of $C$. finmarchicus copepodite stage 4 (C4) reflected the different food treatments (ANOVA; $P=0.015)$. The RNA:DNA ratios for $\mathrm{C} 4$ followed more or less an expected pattern: the copepods that were starved or offered the high-cop treatment (high copepod manipulation) had low ratios compared to the richer food treatments (Rho/Tet and medium-cop). However, the RNA:DNA ratio of $\mathrm{C} 4 \mathrm{~s}$ in the low-cop treatment (not manipulated by copepod grazers) closely resembled the starved and the high-cop treatments. In contrast to C4, C. finmarchicus copepodite stage 5 (C5) was not significantly affected by the different treatments (ANOVA; $P=0.16)($ Fig. 1).

\section{Mesocosms}

We found that different food quantity indicators showed different patterns. Chlorophyll $a$ from the first mesocosm experiment suggested higher food abundance with increasing copepod density. The same pattern was also found in the second experiment, but was measured with another technique (HPLC) (Feuchtmayr, unpublished) and therefore cannot directly be compared. On the other

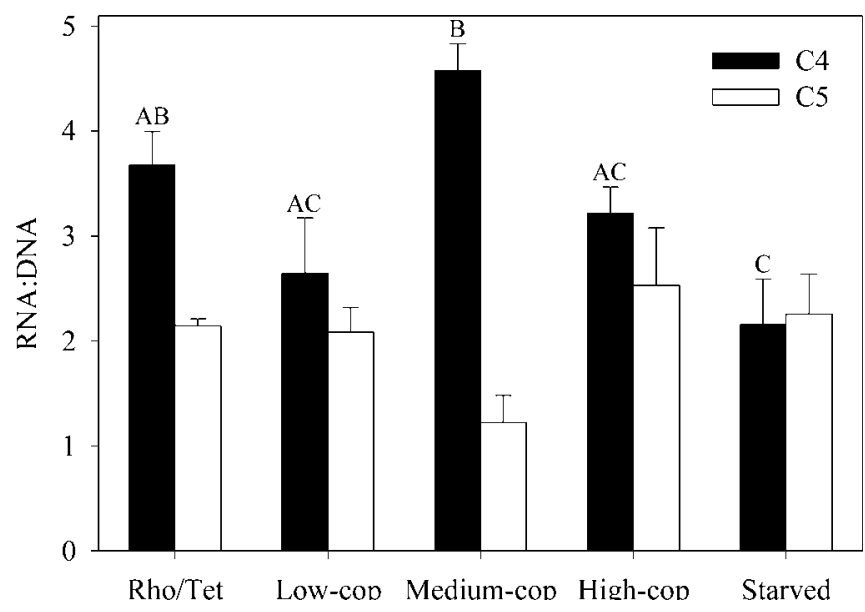

Fig. 1 Calanus finmarchicus. RNA:DNA ratios for C4 and C5 copepodites cultivated in the laboratory for 5 days. Mean and standard error of three measurements are given [treatments are: Rho/Tet enriched with Rhodomonas sp./Tetraselmis sp.; starved particle-free water; low-cop water from control mesocosms (without meso-zooplankton); medium-cop manipulated by low densities of copepod grazers; high-cop manipulated by high densities of copepods]. Identical letters identify non-significant differences for the C4 (Duncan's multiple range test) 
hand, the particulate carbon $(\mathrm{C})$ content from both experiments showed a downward trend, but was not significantly affected by higher numbers of copepods (Fig. 2). At the same time, $\omega 3: \omega 6$ and $\mathrm{C}: \mathrm{N}$ molar ratios both indicated increasing food quality with increasing copepod densities (Fig. 3). These parameters are usually used as indicators of food quality, whereby lower C:N ratios and higher $\omega 3: \omega 6$ ratios indicate higher food quality.

In the mesocosms we aimed to produce a density gradient of copepods from 0-8 (expt 1) and 0-10 (expt 2 ) copepods $1^{-1}$. In the first mesocosm experiment this was achieved; however, in the second experiment the gradient covered a smaller density range (Table 2) (from Saage 2003). Nevertheless, the gradients in both trials were strong enough to induce differences in the grazing zooplankton community. Based on the results presented above, with increasing chlorophyll $a$ content (as a measure of living algae), and increasing quality parameters over the range of copepod densities, one would expect that the condition of the copepods in the enclosures would correlate positively with the copepod densities. However, we observed the opposite pattern, a negative correlation between the RNA:DNA ratio of the animals with copepod density after 6 days. The
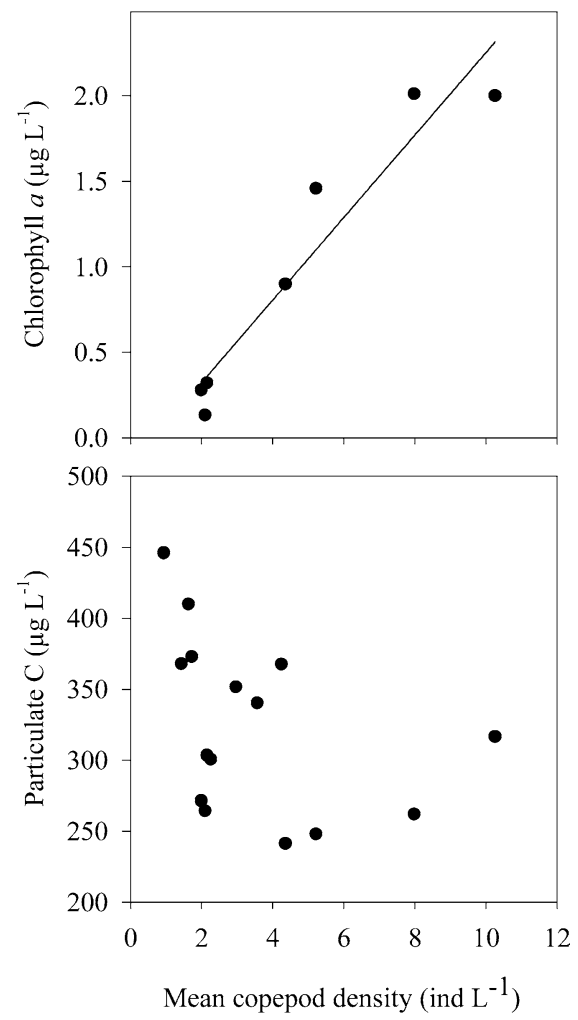

Fig. 2 Different indicators used for food quantity estimations, in relation to copepod densities from day 6 in the mesocosms. For chlorophyll $a$ only the first mesocosm experiment is presented, while for particulate $\mathrm{C}$ both mesocosm experiments are presented. Each data point represents one mesocosm (regression equations are: chlorophyll $a, \quad n=7, \quad y=0.24 x-0.16, \quad r^{2}=0.91, \quad P<0.001$; particulate $\mathrm{C}, n=15, y=-9.87+358, r^{2}=0.17, P=0.12$ )
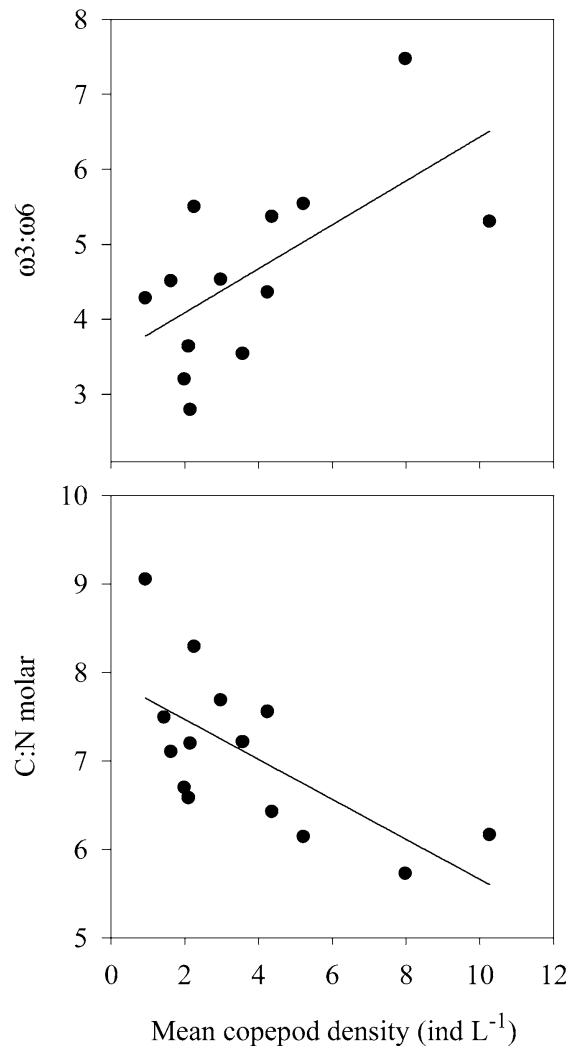

Fig. 3 Mean copepod densities against food quality parameters ( $\omega 3: \omega 6$ ratio and $\mathrm{C}: \mathrm{N}$ molar ratio) from two mesocosm experiments after 6 days of grazing. Each data point represents one mesocosm (regression equations are: $\omega 3: \omega 6, \quad n=13$, $y=0.29 x+3.50, \quad r^{2}=0.40, \quad P=0.019 ; \quad \mathrm{C}: \mathrm{N}$ molar, $n=14$, $\left.y=-0.23 x+7.9, r^{2}=0.44, P=0.0091\right)$

RNA:DNA ratios decreased over the experiments (Fig. 4). Initially, at the start of the experiment, the RNA:DNA ratios were relatively high, and we recorded ratios of approximately 4.7 for both mesocosm experiments. At the first sampling, after 3 days of grazing, the RNA:DNA ratios were still relatively high and there was no apparent negative effect of the different densities. In fact, we even found a positive relationship between RNA:DNA and copepod density (C3-C5 grouped) in the first experiment on day 3 (Fig. 4). In the second experiment, after 3 days, there was no significant relationship between copepod density and RNA:DNA ratios $\left(r^{2}=0.07, P=0.19\right)$. After 6 days of grazing,

Table 2 Actual copepod density in the mesocosms ( $n$ number of observations), mean RNA:DNA ratios ( $\pm \mathrm{SD}$ in parentheses) for copepodite stage 4 from day 6 of two consecutive mesocosm experiments

\begin{tabular}{|c|c|c|c|c|c|}
\hline \multicolumn{3}{|c|}{ Experiment 1} & \multicolumn{3}{|c|}{ Experiment 2} \\
\hline $\begin{array}{l}\text { Copepods } \\
\text { (ind. } 1^{-1} \text { ) }\end{array}$ & $n$ & RNA:DNA & $\begin{array}{l}\text { Copepods } \\
\text { (ind. } 1^{-1} \text { ) }\end{array}$ & $n$ & RNA:DNA \\
\hline 2.06 & 2 & $2.89(0.17)$ & 1.34 & 3 & $3.19(0.21)$ \\
\hline 1.98 & 1 & $2.49(0.00)$ & 1.54 & 3 & $2.71(0.06)$ \\
\hline 4.74 & 2 & $2.27(0.23)$ & 2.64 & 3 & $2.64(0.17)$ \\
\hline 8.81 & 2 & $1.26(0.37)$ & 3.91 & 4 & $2.26(0.29)$ \\
\hline
\end{tabular}


Fig. 4 Calanus finmarchicus. RNA:DNA ratios and mean copepod density, after 3 and 6 days of grazing, in two consecutive mesocosm trials. The line through the data points represents the significant linear regressions for all $\mathrm{C} 3-\mathrm{C} 5$ copepodites grouped. The dashed horizontal lines denote the RNA:DNA ratio of $\mathrm{C} 4$ after 5 days of starvation from Fig. 1 (significant regressions are: expt $1 /$ day $3, n=22$, $y=0.15 x+2.63, r^{2}=0.18$, $P=0.047$; expt $1 /$ day $6, n=18$, $y=-0.13 x+3.11, r^{2}=0.44$, $P=0.003$; expt $2 /$ day $6, n=29$, $y=-0.20 x+3.12, r^{2}=0.31$, $P=0.002)$

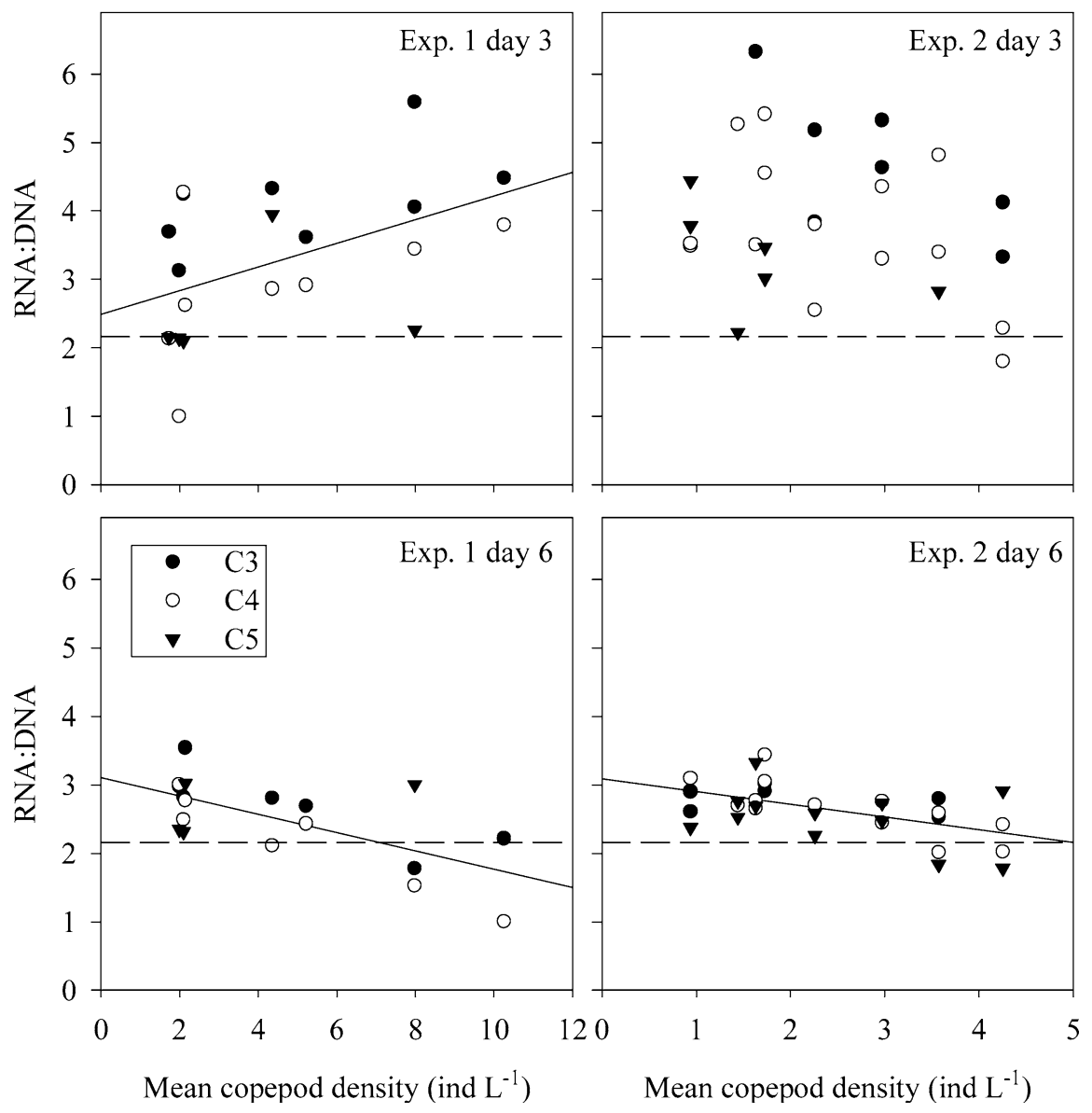

however, the $C$. finmarchicus RNA:DNA ratios decreased with increasing copepod density in both mesocosm studies (Fig. 4). Between the two mesocosm experiments, the copepodite stage distribution differed slightly, with mostly $\mathrm{C} 3$ and $\mathrm{C} 4$ in the first experiment and mainly $\mathrm{C} 4$ and $\mathrm{C} 5$ in the second experiment. Hence, only the $\mathrm{C} 4$ copepodite stage was abundant during both experiments, and available to test for differences in RNA:DNA ratios against different food parameters, parallel over both mesocosm studies. Fortunately, this particular stage also seemed to be the most sensitive copepodite stage to food changes (Fig. 1). Hence, we found that $C$. finmarchicus' nutritional status was negatively linked to increasing concentrations of chlorophyll $a$, while the carbon content did not impose a significant effect on the $C$. finmarchicus RNA:DNA ratios (Table 3). The $C$. finmarchicus nutritional condition on day 6 was significantly correlated to the $\omega 3: \omega 6$ and $\mathrm{C}: \mathrm{N}$ molar ratios (Table 3), but surprisingly the direction of the correlation was such that the RNA:DNA ratio of the animals decreased with increasing food quality.

Therefore, we investigated alternative food quality factors that could explain the patterns described above. After 6 days of copepod grazing in both mesocosm experiments, distinct changes in size distribution of the plankton were found. Increasing copepod densities had an impact on the total biovolumes in the mesocosms
(Fig. 5). However, this decrease was mostly due to high biovolumes in a few low copepod density mesocosms, and otherwise the total biovolumes did not show a strong effect with the increasing copepod densities (Fig. 5). On the other hand, analysis of size fractions of the plankton makes the effects of copepod grazing more apparent. With increasing copepod densities the biovolumes of larger cells $\left(>1000 \mu \mathrm{m}^{3}\right)$ decreased sharply, while smaller plankton particles increased $\left(<1000 \mu \mathrm{m}^{3}\right)$ (Fig. 5). Moreover, the RNA:DNA ratios of $C$. finm-

Table 3 Calanus finmarchicus. Linear and non-linear regressions between seston food quantity/quality parameters and copepodite stage 4 RNA:DNA ratios after 6 days of grazing from two consecutive mesocosm studies. The food parameters are: particulate carbon, total biovolume given as the sum of plankton particles smaller and larger than $1000 \mu \mathrm{m}^{3}$, plankton particles smaller and larger than $1000 \mu \mathrm{m}^{3}$, seston $\mathrm{C}: \mathrm{N}$ and $\omega 3: \omega 6$ ratios. The linear regression equation is $y=\mathrm{a} x+\mathrm{b}$, and the non-linear equation for $>1000 \mu \mathrm{m}^{3}$ is $y=\mathrm{a} x^{\mathrm{b}}$

\begin{tabular}{llllll}
\hline Parameters & $n$ & $\mathrm{a}$ & $\mathrm{b}$ & $r^{2}$ & $P$ \\
\hline Particulate C & 20 & $3.75 \times 10^{-3}$ & 1.24 & 0.15 & 0.09 \\
Chlorophyll $a$ & 7 & -0.75 & 2.95 & 0.75 & 0.0125 \\
Total biovol. & 20 & $2.05 \times 10^{6}$ & 0.19 & 0.32 & 0.0103 \\
$>1000 \mu \mathrm{m}^{3}$ & 20 & 0.87 & 0.087 & 0.79 & $<0.001$ \\
$<1000 \mu \mathrm{m}^{3}$ & 20 & $-1.32 \times 10^{-6}$ & 3.22 & 0.52 & $<0.001$ \\
$\mathrm{C}: \mathrm{N}$ & 19 & 0.39 & -0.37 & 0.35 & 0.0085 \\
$\omega 3: \omega 6$ & 17 & -0.26 & 3.56 & 0.28 & 0.0277 \\
\hline
\end{tabular}


Fig. 5 Biovolumes of phytoplankton and microplankton, in relation to mean copepod densities in the mesocosms. Biovolumes are the total and the summarised fraction of smaller and larger than $1000 \mu^{3}$ in the mesocosms. Each data point represents one mesocosm on day 6 for both consecutive experiments (regression equations are: total biovolume, $n=15 ; y=2.05 \times 10^{6} \mathrm{e}^{-0.20 x}$,

$r^{2}=0.32, P<0.0103$; $<1000 \mu \mathrm{m}^{3}, n=15$, $y=2.11 \times 10^{5}+9.06 \times 10^{4}$, $r^{2}=0.60, P<0.001$ $>1000 \mu \mathrm{m}^{3}, n=15$, $y=4.89 \times 10^{6} \mathrm{e}^{-0.88 x}$, $\left.r^{2}=0.83, P<0.001\right)$
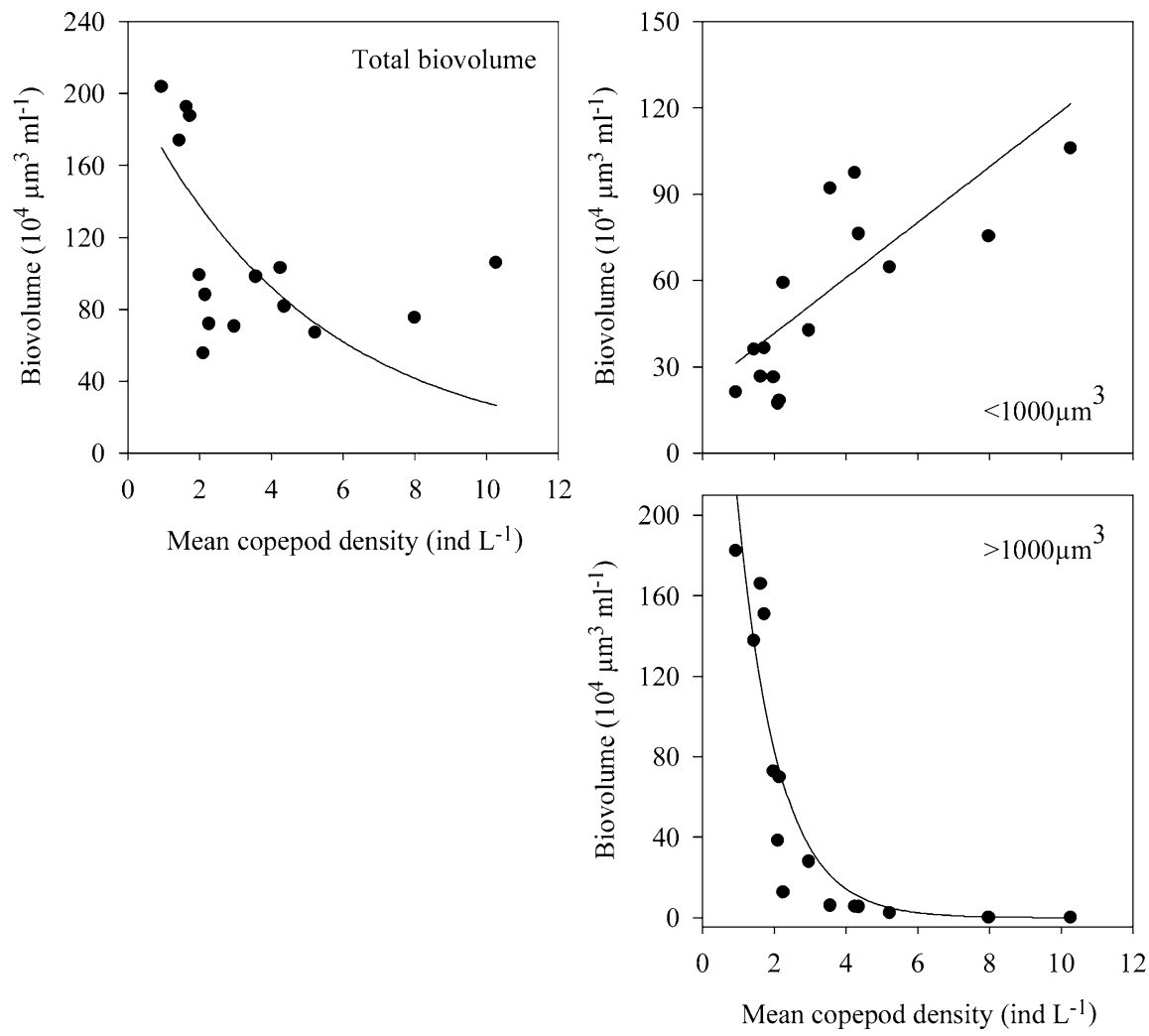

archicus were closely related to biovolumes of the two size fractions of the plankton (Fig. 6). Where the increasing biovolumes of larger particles positively affected the $C$. finmarchicus RNA:DNA ratios (Fig. 6; Table 3), the increasing biovolumes of smaller particles had a negative impact on the $C$. finmarchicus RNA:DNA ratios (Fig. 6; Table 3).

We investigated if the induced size distribution of the plankton affected the plankton food quality. Hence, we tested whether the $\mathrm{C}: \mathrm{N}$ and the $\omega 3: \omega 6$ ratios were correlated with the plankton size fractions (smaller and larger than $1000 \mu^{3}$ ). We found that with increasing biovolumes of smaller plankton particles (mostly consisting of Teleaulax sp., Skeletonema sp. and nanoflagellates) the food quality increased (Fig. 7). On the other hand, we found no relationship between $\mathrm{C}: \mathrm{N}$ and $\omega 3: \omega 6$ ratios and the changes in the biovolume of the larger fraction (C:N, $r^{2}=0.14, P=0.11$ and $\omega 3: \omega 6, r^{2}=0.09$, $P=0.70)$. Moreover, in a backward stepwise multiple linear regression including common food quality parameters, the biovolumes of smaller particles $\left(<1000 \mu \mathrm{m}^{3}\right)$ exhibited the only significant regression, explaining $52 \%$ of the variation in C. finmarchicus RNA:DNA ratios.

\section{Discussion}

We investigated the impact of copepods on the plankton community and also the resulting effects on the copepod
Fig. 6 Calanus finmarchicus. RNA:DNA ratios (C4) and the biovolumes of phytoplankton, ciliates and heterotrophic nanoflagellates, grouped as biovolumes consisting of factions larger and smaller than $1000 \mu \mathrm{m}^{3}$ after 6 days for two consecutive experiments. Each data point represents one replicate sample, from each mesocosm. The dashed horizontal lines denote the RNA:DNA ratio of $\mathrm{C} 4$ after 5 days of starvation from Fig. 1. For regression equations see Table 3

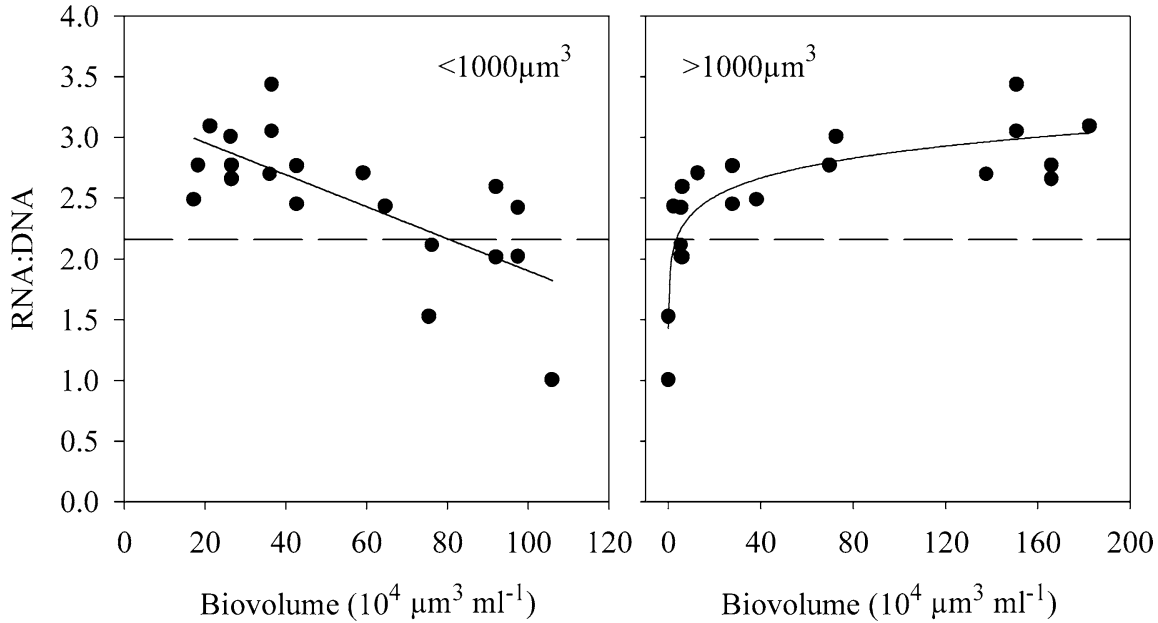



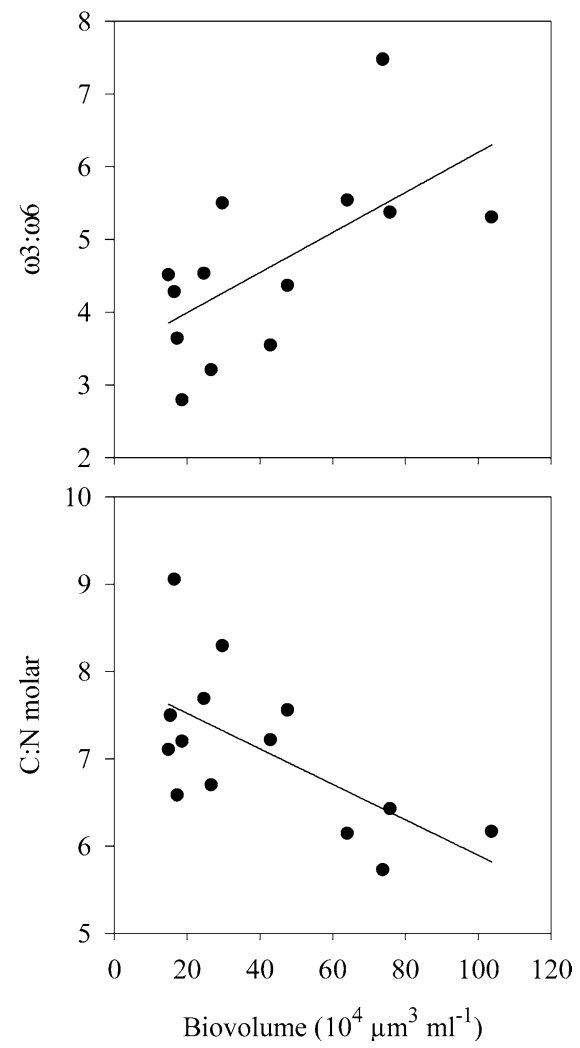

Fig. 7 The relation between the $\mathrm{C}: \mathrm{N}$ molar ratio and the $\omega 3: \omega 6$ ratio and the biovolumes of phytoplankton smaller than $1000 \mu \mathrm{m}^{3}$ (regression equations are: $\omega 3: \omega 6, n=13, y=2.76 \times 10^{-6} x+3.43$, $r^{2}=0.40, P=0.021 ; \mathrm{C}: \mathrm{N}$ molar, $n=14, y=-2.03 \times 10^{-6} x+7.93$, $r^{2}=0.41, P=0.014$

grazer. The nutritional status of copepods can be assessed through various methods (e.g. egg production, life-history studies, or RNA:DNA measurements). Our studies were performed in spring, when copepod reproduction was low. In fact, we only caught a few adult Calanus finmarchicus, which made an egg production study infeasible. Moreover, in the mesocosms, the plankton showed a rapid response to the gradient in copepod density, which made a long-term, life-history study futile. Hence, the only workable determinant of nutritional status of $C$. finmarchicus was the measurement of RNA:DNA, which has developed into a useful tool for copepods both in field and laboratory studies (e.g. Saiz et al. 1998; Wagner et al. 1998, 2001). Further, the small methodological variation in the variability test indicated that our experimental protocol, modified from Clemmesen (1993), also was applicable to measure growth potential for $C$. finmarchicus copepodite stages (Table 1).

\section{Laboratory study}

In our laboratory experiment, we found that $C$. finmarchicus copepodite stages responded differently to the different food treatments. Copepodite stage 4 was most affected by the different food treatments (Fig. 1). The RNA:DNA ratio of the $\mathrm{C} 4$ followed, more or less, the expected pattern: the highest ratios were found in the enriched Rho/Tet and the medium-cop treatments. The starved animals had the lowest ratios, and the low-cop and high-cop treatments were only slightly higher (Fig. 1). On the other hand, copepodite stage 5 did not respond significantly to the different food treatments (Fig. 1). Previous studies have described increasing RNA:DNA ratios and food density relationships with increasing copepodite stages of $C$. finmarchicus (Wagner et al. 1998, 2001). In these studies, the pattern was consistent at several food concentrations, but was less pronounced at the lower food concentrations. Nevertheless, in our study this pattern was not found, instead C5 had the same or even slightly lower ratios compared to $\mathrm{C} 4$ (Fig. 1). These differences are difficult to explain; however, since $\mathrm{C} 4$ clearly responded to the various treatments, we conclude that food was not limiting in any treatment. On the other hand, the random variations in RNA:DNA ratios for C5 could potentially be explained by differences in body size. $\mathrm{C} 5$ is larger than $\mathrm{C} 4$, and thus may respond more slowly to food quality changes. Yet another explanation could be that, for $C$. finmarchicus, C5 is the main overwintering stage and during this stage the storage of wax esters increases. This transition occurs in spring, and during this phase the copepodites have an arrested development (reviewed in Hirche 1996). Potentially the C5s had already reached the preparatory stage preceding the overwintering resting stage. On the Norwegian coast this phase is normally initiated in May-June (e.g. Marker et al. 2003), which is about 1 month later than the time period of our study. However, the temperatures in April and May 2002 exceeded the monthly mean temperatures by around $4^{\circ} \mathrm{C}$ compared to other years, which might have moved the accumulation process forward in time, and thus we would expect no food effect on RNA:DNA ratios.

\section{Mesocosms}

The food quantity, estimated as particulate carbon, was not correlated to the copepod densities or to the C. finmarchicus RNA:DNA ratios. Hence, the grazing copepods were not limited in terms of particulate C (Fig. 2; Table 3). Another food abundance indicator, the chlorophyll $a$ content, was even positively affected by higher copepod grazing (Fig. 2), suggesting that copepod grazing in fact stimulated food abundance. On the other hand, the RNA:DNA ratios of $C$. finmarchicus did not reflect an increased food abundance. On the contrary, we found decreasing RNA:DNA ratios with this apparent food quantity increase (Table 3). Common food quality indicators, $\mathrm{C}: \mathrm{N}$ and $\omega 3: \omega 6$ ratios, showed an increasing food quality with higher copepod densities (Fig. 3). These food quality parameters were correlated to the nutritional condition of $C$. finmarchicus (Table 3 ). However, the regressions were contrary to our a priori 
expectations, suggesting that the copepods had a lower nutritional status when these two food quality parameters indicated a higher quality (Table 3 ). This contrasts with results of earlier studies, in which egg production was positively correlated to increasing $\omega 3: \omega 6$ ratios of the plankton (e.g. Jónasdóttir et al. 1995).

During the course of the experiments, we found that, at all copepod densities, over time the RNA:DNA ratios decreased (Fig. 4). However, the copepod densities did not have a negative impact on the RNA:DNA ratios of C. finmarchicus until after 6 days of grazing (Fig. 4). In contrast to our laboratory experiment, this decrease appeared to be similar over all copepodite stages. Nevertheless, the RNA:DNA ratios were not elevated with increasing copepodite stages, which was consistent with the results from the laboratory experiment.

Copepod grazing had a strong impact on the plankton size distribution in mesocosms (Fig. 5). Low copepod densities grazed the larger plankton particles down, and the contrary was found for the smaller plankton that increased. In fact the larger plankton were almost completely removed in the higher copepod densities (Fig. 5). We observed the same effect in both mesocosm studies, even though the mean copepod density was lower than intended in the second trial (Table 2). This was consistent with previous studies that described similar effects in ecosystems dominated by copepods (Rothhaupt 1997; Sommer et al. 2001). The decrease of larger particles is explained by the size selective grazing pressure that copepods induce on the plankton community (Frost 1972). The selective feeding of copepods is sensitive, and they can even distinguish between particles of different taste and nutritional composition (Paffenhöfer and Van Sant 1985; DeMott 1986; Cowles et al. 1988; Butler et al. 1989). Hence, when copepods are the main dominating grazer they induce specific grazing pressures that influence the composition of the plankton community (Fig. 5). The consequential increase of smaller particles can be explained in several ways: during copepod grazing the copepods break larger particles (mostly chains) into smaller ones (O'Connors et al. 1976), or the copepods remove the larger particles, which would leave more nutrients available for the smaller particles to utilize. It should be noted that smaller cells are more effective in taking up nutrients, as such cells have shorter generation times and larger surface to volume ratios. Another potential explanation is that the increased predation pressure of the copepods on the micro-zooplankton decreases the grazing pressure on the smaller particles (Zöllner et al. 2003).

When food quantity was classified in regard to favourable particle sizes, there was a clear pattern in C. finmarchicus RNA:DNA status. With increasing biovolumes of larger particles $\left(>1000 \mathrm{~m}^{3}\right)$ C. finmarchicus RNA:DNA ratios were elevated (Fig. 6; Table 3). On the contrary, when the biovolumes of the smaller particles $\left(<1000 \mu^{3}\right)$ increased, the RNA:DNA ratios decreased (Fig. 6; Table 3). This can be interpreted in two ways: either, the decrease of larger particles was the limiting factor and the $C$. finmarchicus could not find enough suitable food particles (Fig. 6), or the increasing volumes of smaller particles impeded foraging on the less abundant larger particles (Fig. 6). The increase in food quality in the mesocosm was closely related to the increase of smaller plankton particles $\left(<1000 \mu^{3}\right)$ (Fig. 7). The increased food quality can be linked to the increases in small diatoms, cryptophyceans and nanoflagellates, whereby at least the diatoms and cryptophyceans are rich in various $\omega 3$ fatty acids (Olsen 1999). Moreover, the increases in the small plankton particles are also consistent with the increase in chlorophyll $a$ content. This shows that when copepods are numerically dominant, the chlorophyll $a$ content should not be used as an indicator of food abundance. During similar conditions, the particle size distribution is a far better indicator of food availability.

The removal of large particles and the consequential food quality increase could be beneficial for non-selective filter feeders that can utilize the smaller particles. This has previously been shown in freshwater ecosystems, where copepod grazing positively affected Daphnia growth (Becker et al. 2004). In marine systems this nonselective feeding could be played by ciliates, appendicularians (Bedo et al. 1993), or by cladocerans. For example Podon sp. can ingest small centric diatoms (from $4 \mu \mathrm{m}$ ) such as Skeletonema costatum (Kim et al. 1989). On the other hand, calanoid copepods have been suggested to suppress appendicularian eggs and juveniles (F. Sommer et al. 2003; Lopez-Urrutia et al. 2004). This type of suppression could also be the case for marine cladocerans, and has been shown for ciliates (Zöllner et al. 2003). Thus, the eventual food benefits caused by calanoid copepod grazing are most likely unused when the predation pressure on earlier stages of the organisms that could use these resources is high. Nevertheless, this suggests that when copepods decrease in numbers, thus lowering the suppression of the earlier life stages of those organisms that could consume the smaller algal cells, there is a high density of high quality food available for the opportunistic grazer to utilise.

Since we could not detect a relationship between particulate carbon content and the RNA:DNA ratio, we conclude that, in our mesocosms, C. finmarchicus (at high copepod densities) were food limited by the low abundance of favourable sized food particles. The size distribution differences of the food originated from the selective feeding behaviour of the copepod grazers. This indicates that the selective copepods in higher densities were not only transforming the plankton size distribution, but also that the selective feeding increased the $C$. finmarchicus competition for food particles. Thus, we suggest that selective feeding indirectly resulted in lower RNA:DNA ratios in C. finmarchicus. The copepod densities in the Hopavågen fjord are of the same order of magnitude as the highest copepod density we used in the mesocosm experiments. Therefore, we suggest that the changes in the plankton community and the resulting effects on the plankton grazer are of ecological relevance. 
Acknowledgements This work would not have been possible without the IfM-MPIL food web team. We thank the European Commission's programme (Improving Human Potential-Access to Research infrastructure) for the access to Trondheim Marine Systems Research Infrastructure in Hopavågen, Sletvik, Norway. $\varnothing$. Leiknes and A. Neyts are especially acknowledged for their valuable help during our stay in Norway. W. DeMott provided interesting discussions and constructive criticism on earlier drafts of this manuscript. This research was partly supported by DFGgrants: BO1488/3-1, SA 638/1-1, SO145/19-1, JU367/4-1 and CNPq (Brazil).

\section{References}

Båmstedt U (1983) RNA concentration in zooplankton-seasonalvariation in boreal species. Mar Ecol Prog Ser 11:291-297

Båmstedt U, Skjoldal HR (1980) RNA concentration of zooplankton-relationship with size and growth. Limnol Oceanogr 25:304-316

Becker C, Feuchtmayr H, Brepohl D, Santer B, Boersma M (2004) Differential impacts of copepods and cladocerans on lake seston, and resulting effects on zooplankton growth. Hydrobiologia (in press)

Bedo AW, Acuna JL, Robins D, Harris RP (1993) Grazing in the micron and the submicron particle size range - the case of Oikopleura dioica (Appendicularia). Bull Mar Sci 53:214

Beutler M, Wiltshire KH, Meyer B, Moldaenke C, Luring C, Meyerhofer M, Hansen UP, Dau H (2002) A fluorometric method for the differentiation of algal populations in vivo and in situ. Photosynth Res 72:39-53

Butler NM, Suttle CA, Neill WE (1989) Discrimination by freshwater zooplankton between single algal cells differing in nutritional status. Oecologia 78:368-372

Clemmesen C (1993) Improvements in the fluorometric determination of the RNA and DNA content of individual marine fish larvae. Mar Ecol Prog Ser 100:177-183

Clemmesen C (1994) The effect of food availability, age or size on the RNA/DNA ratio of individually measured herring larvae-laboratory calibration. Mar Biol 118:377-382

Clemmesen C (1996) Importance and limits of RNA/DNA ratios as a measure of nutritional condition in fish larvae. In: Watanabe Y, Yamashita Y, Oozeki Y (eds) Survival strategies in early life stages of marine resources. Balkema, Rotterdam, pp 67-82

Clemmesen C, Buehler V, Carvalho G, Case R, Evans G, Hauser L, Hutchinson WF, Kjesbu OS, Mempel H, Moksness E, Otteraa H, Paulsen H, Thorsen A, Svaasand T (2003) Variability in condition and growth of Atlantic cod larvae and juveniles reared in mesocosms: environmental and maternal effects. J Fish Biol 62:706-723

Cowles TJ, Olson RJ, Chisholm SW (1988) Food selection by copepods' discrimination on the basis of food quality. Mar Biol $100: 41-50$

DeMott WR (1986) The role of taste in food selection by freshwater zooplankton. Oecologia 69:334-340

Frangoulos M, Guisande C, Maneiro I, Riveiro I, Franco J (2000) Short-term and long-term effects of the toxic dinoflagellate Alexandrium minutum on the copepod Acartia clausi. Mar Ecol Prog Ser 203:161-169

Frost BW (1972) Effects of size and concentration of food particles on feeding behavior of the marine planktonic copepod Calanus pacificus. Limnol Oceanogr 17:805-815

Frost BW (1977) Feeding behavior of Calanus pacificus in mixtures of food particles. Limnol Oceanogr 22:472-491

Hirche HJ (1996) Diapause in the marine copepod, Calanus finmarchicus - A review. Ophelia 44:129-143

Ianora A, Poulet SA, Miralto A (2003) The effects of diatoms on copepod reproduction: a review. Phycologia 42:351-363
Jónasdóttir SH (1994) Effects of food quality on the reproductive success of Acartia tonsa and Acartia hudsonica: laboratory observations. Mar Biol 121:67-81

Jónasdóttir SH, Fields D, Pantoja S (1995) Copepod egg production in Long Island Sound, USA, as a function of the chemical composition of seston. Mar Ecol Prog Ser 119:87-98

Kaartvedt S (2000) Life history of Calanus finmarchicus in the Norwegian Sea in relation to planktivorous fish. ICES J Mar Sci 57:1819-1824

Kim SW, Onbe T, Yoon YH (1989) Feeding habits of marine cladocerans in the Inland Sea of Japan. Mar Biol 100:313-318

Kiørboe T (1989) Phytoplankton growth rate and nitrogen content: implications for feeding and fecundity in a herbivorous copepod. Mar Ecol Prog Ser 55:229-234

Kleppel GS, Burkart CA (1995) Egg production and the nutritional environment of Acartia tonsa: the role of food quality in copepod nutrition. ICES J Mar Sci 52:297-304

Laabir M, Poulet SA, Harris RP, Pond DW, Cueff A, Head RN, Ianora A (1998) Comparative study of the reproduction of Calanus helgolandicus in well-mixed and seasonally stratified coastal waters of the western English Channel. J Plankton Res 20:407-421

Lopez-Urrutia A, Harris RP, Smith T (2004) Predation by calanoid copepods on the appendicularian Oikopleura dioica. Limnol Oceanogr 49:303-307

Marker T, Andreassen P, Arashkewich E, Hansen BW (2003) Lipid deposition and sexual maturation in cohorts of Calanus finmarchicus (Gunnerus) originating from Bergen $\left(60^{\circ} \mathrm{N}\right)$ and Tromsø $\left(69^{\circ} \mathrm{N}\right)$ reared in Tromsø, Norway. Mar Biol 143:283296

Nakata K (1990) Abundance of nauplii and protein synthesis activity of adult female copepods in the Kuroshio front during the Japanese sardine spawning season. J Oceanogr Soc Jpn 46:219-229

Nakata K, Nakano H, Kikuchi H (1994) Relationship between egg productivity and RNA/DNA ratio in Paracalanus sp. in the frontal waters of the Kuroshio. Mar Biol 119:591-596

O'Connors HB, Small LF, Donaghay PL (1976) Particle-size modification by 2 size classes of estuarine copepod Acartia clausi. Limnol Oceanogr 21:300-308

Olsen Y (1999) Lipids and essential fatty acids in aquatic food webs: What can freshwater ecologists learn from mariculture? In: Arts MT, Wainman BC (eds) Lipids in freshwater ecosystems. Springer, New York Heidelberg Berlin, pp 161-202

Paffenhöfer GA (2002) An assessment of the effects of diatoms on planktonic copepods. Mar Ecol Prog Ser 227:305-310

Paffenhöfer GA, Van Sant KB (1985) The feeding response of a marine planktonic copepod to quantity and quality of particles. Mar Ecol Prog Ser 27:55-65

Richardson K, Jónasdóttir SH, Hay SJ, Christoffersen A (1999) Calanus finmarchicus egg production and food availability in the Faroe-Shetland Channel and northern North Sea: OctoberMarch. Fish Oceanogr 8:153-162

Rothhaupt KO (1997) Grazing and nutrient influences of Daphnia and Eudiaptomus on phytoplankton in laboratory microcosms. J Plankton Res 19:125-139

Saage A (2003) Populationsentwicklungen des Zooplankton in Mesokosmosexperimenten. Diplomarbeit, Christian-AlbrechtsUniversität, Kiel, Germany

Saiz E, Calbet A, Fara A, Berdalet E (1998) RNA content of copepods as a tool for determining adult growth rates in the field. Limnol Oceanogr 43:465-470

Schmidt K, Koski M, Engström-Öst J, Atkinson A (2002) Development of Baltic Sea zooplankton in the presence of a toxic cyanobacterium: a mesocosm approach. J Plankton Res 24:979-992

Sommer F, Hansen T, Feuchtmayr H, Santer B, Tokle N, Sommer U (2003) Do calanoid copepods suppress appendicularians in the coastal ocean? J Plankton Res 25:869-871

Sommer U, Sommer F, Santer B, Jamieson C, Boersma M, Becker C, Hansen T (2001) Complementary impact of copepods and cladocerans on phytoplankton. Ecol Lett 4:545-550 
Sommer U, Sommer F, Santer B, Zöllner E, Jürgens K, Jamieson C, Boersma M, Gocke K (2003) Daphnia versus copepod impact on summer phytoplankton: functional compensation at both trophic levels. Oecologia 135:639-647

Sterner RW, Hessen DO (1994) Algal nutrient limitation and the nutrition of aquatic herbivores. Annu Rev Ecol Syst 25:1-29

Turner JT, Lincoln JA, Cembella AD (1998) Effects of toxic and non-toxic dinoflagellates on copepod grazing, egg production and egg hatching success. In: Reguera B, Blanco J, Fernandez ML, Wyatt $\mathrm{T}$ (eds) Harmful algae. Xunta de Galicia and Intergovernmental Oceanographic Commission of UNESCO, Paris

Twombly S, Clancy N, Burns CW (1998) Life history consequences of food quality in the freshwater copepod Boeckella triarticulata. Ecology 79:1711-1724

Villar-Argaiz M, Sterner RW (2002) Life history bottlenecks in Diaptomus clavipes induced by phosphorus-limited algae. Limnol Oceanogr 47:1229-1233

Villar-Argaiz M, Medina-Sanchez JM, Carrillo P (2002) Linking life history strategies and ontogeny in crustacean zooplankton: implications for homeostasis. Ecology 83:1899-1914 von Elert E (2002) Determination of limiting polyunsaturated fatty acids in Daphnia galeata using a new method to enrich food algae with single fatty acids. Limnol Oceanogr 47:1764-1773

Vrede T, Persson J, Aronsen G (2002) The influence of food quality (P:C ratio) on RNA:DNA ratio and somatic growth rate of Daphnia. Limnol Oceanogr 47:487-494

Wagner M, Durbin E, Buckley L (1998) RNA:DNA ratios as indicators of nutritional condition in the copepod Calanus finmarchicus. Mar Ecol Prog Ser 162:173-181

Wagner MM, Campbell RG, Boudreau CA, Durbin EG (2001) Nucleic acids and growth of Calanus finmarchicus in the laboratory under different food and temperature conditions. Mar Ecol Prog Ser 221:185-197

Wiltshire KH, Boersma M, Möller A, Buhtz H (2000) Extraction of pigments and fatty acids from the green alga Scenedesmus obliquus (Chlorophyceae). Aquat Ecol 34:119-126

Zöllner E, Santer B, Boersma M, Hoppe HG, Jürgens K (2003) Cascading predation effects of Daphnia and copepods on microbial food web components. Freshw Biol 48:2174-2193 